\title{
Admissibility of Statements Obtained as a Result of "Private Torture" or "Private" Inhuman Treatment as Evidence in Criminal Proceedings: Emergence of a New European Standard?
}

Admissibilidade de declarações obtidas como resultado de "tortura privada" ou tratamento inumano "privado" como prova no processo penal: surgimento de um novo parâmetro europeu?

\section{Małgorzata Wąsek-Wiaderek ${ }^{1}$}

The John Paul II Catholic University of Lublin, Poland malgorzata.wasek-wiaderek@kul.pl

http://orcid.org/0000-0001-9761-3177

\begin{abstract}
This article presents a critical approach to the position of the European Court of Human Rights on the admissibility of evidence (recorded statements) obtained as a result of "private torture or inhuman treatment", while such recordings were produced outside of and for purposes other than the criminal proceedings. In accordance with the recent judgment of the Court (case Ćwik v. Poland), the use of this evidence in the criminal proceedings conducted against a third party, not against a tortured person, renders such proceedings as a whole automatically unfair, in breach of Article 6 of the European Convention on Human Rights. In the author's opinion, the ECtHR does not attach adequate importance to the fact that the use of such evidence cannot have any impact on the scope or level of protection against torture or other forms of cruel treatment, provided in the framework of criminal proceedings. It is argued in this paper that recorded statements produced prior to criminal proceedings and not for purposes of those proceedings by private individuals, without the instigation, consent, or acquiescence
\end{abstract}

1 Professor at the John Paul II Catholic University of Lublin, Poland; Head of Department of Criminal Procedure; judge of the Supreme Court of Poland (Criminal Chamber). PhD in Law. 
of public officials, by methods contrary to Article 3 of the Convention, shall be admissible evidence. Consequently, the European Court should not have questioned the admissibility of such evidence, but rather assess the fairness of criminal proceedings as a whole.

KeYwords: criminal proceedings; admissibility of evidence; torture; European Convention on Human Rights, fair trial.

Resumo: Este artigo apresenta uma análise crítica da posição firmada pelo Tribunal Europeu de Direitos Humanos sobre a admissibilidade da prova (declarações gravadas) obtidas como resultado de "tortura privada ou tratamento inumano", quando essa gravação tenha sido produzida fora de um processo criminal e não a ele direcionada. Conforme a visão do Tribunal, recentemente assentada (caso Ćwik v. Poland), o uso dessa prova em um processo criminal conduzido contra terceira pessoa, não contra a pessoa torturada, acarreta que esse processo seja automaticamente considerado injusto, em violação do art. 6 da Convenção Europeia de Direitos Humanos. Sustenta-se que a decisão do Tribunal não ponderou adequadamente a importância do fato de que o uso dessa prova não pode ter qualquer impacto na finalidade ou no nível de proteção contra a tortura ou outras formas de tratamento cruel, conforme as diretrizes do processo penal. Afirma-se que as declarações gravadas produzidas por indivíduos privados, sem o consentimento ou autorização de agentes públicos, anteriormente ao processo penal e não a ele dirigidas, por métodos contrários ao artigo 3 da Convenção devem ser consideradas provas admissíveis. Consequentemente, o Tribunal Europeu não deveria ter questionado a admissibilidade dessa prova, mas verificado a adequação do processo penal em sua integralidade às diretrizes do justo processo.

PalaVRas-Chave: processo penal; admissibilidade da prova; tortura; Tribunal Europeu de Direitos Humanos; processo justo.

\section{INTRODUCTION}

The article aims to answer the question of whether under Article 6 of the Convention for the Protection of Human Rights and Fundamental Freedoms ${ }^{2}$ criminal proceedings can be considered fair if

2 Council of Europe Convention on the Protection of Human Rights and Fundamental Freedoms, adopted on 4 November 1950. Hereafter referred to as "the Convention" or "ECHR". 
they rely on statements obtained outside the proceedings through torture or inhuman treatment conducted only by "private individuals" and not through investigative authorities or other public officials involved in obtaining them. Accordingly, the study seeks to assess the admissibility of evidentiary use of recorded statements (declarations), expressed during private interrogations as a result of the aforesaid unlawful methods, if such records were subsequently secured, or obtained by investigative authorities through lawful activities. The level of protection from torture, inhuman or degrading treatment or punishment to be ensured by investigative or judicial authorities in criminal proceedings is fundamental in addressing this question. Consequently, a few specific questions can be framed: does the standard of fair criminal proceedings only prohibit the use of evidence obtained in violation of Article 3 of the Convention by public officials, upon their consent or acquiescence or by other person acting in an official capacity, or does the prohibition also extend to evidence obtained by private individuals, as long as such evidence is collected with the intent of using it in pending or future criminal proceedings? Finally, there is the most far-reaching question of whether evidentiary use of recorded statements obtained by private individuals outside of and other than for the purpose of use in criminal proceedings would violate the standard of fairness of the proceedings.

In order to answer the above questions, it is essential to determine the subjective scope of application of such evidence, namely whether recorded statements forced in private acts of torture or inhuman treatment are intended as evidence in proceedings against the person who made the statement or against a third party. In the author's view, the use of such evidence in proceedings against the victim of treatment contrary to Article 3 ECHR would undermine his/her right to silence.

However, it is argued in this paper that the European standard of fair trial does not prohibit the use of such tainted evidence (recording of private interrogations) in the proceedings conducted against a third person if it is obtained outside those proceedings and not for the purposes of those proceedings.

Having analyzed the aforesaid problems will help tackle a more general question: Is there a European standard already established in this area, or is it yet to be fully developed? 
The article consists of two main chapters. The first one concerns the admissibility of evidence obtained by public officials in violation of Article 3 of the Convention. In this section the European standard on this issue is also compared to universal one, stemming from UN international treaties. The second chapter focuses on the admissibility of statements obtained under the same prohibited methods but by private individuals. This section also contains a critical analysis of the judgment of the ECtHR delivered in the Ćwik v. Poland case as well as reasons put forward in the joint dissenting opinion of two judges attached to this judgment. In the end, the author presents his own concept of assessing the fairness of criminal proceedings in which the court relied on private evidence obtained in the circumstances occurring in Ćwik v. Poland.

\section{RESTRICTIONS ON ADMISSIBILITY OF EVIDENCE OBTAINED BY public officials in Violation of Article 3 ECHR}

Neither the Convention nor any other international agreement concluded between the member states of the Council of Europe regulates the admissibility of evidence in criminal proceedings. The European Court of Human Rights ${ }^{3}$ has repeatedly held that the issue of admissibility of evidence in criminal proceedings is beyond its assessment capability when examining complaints regarding a fair criminal trial guaranteed under Article 6 ECHR. Therefore, any use of an illegally obtained evidence in criminal proceedings should result in the assessment of the fairness of the proceedings as a whole rather than the assessment of admissibility of such evidence. ${ }^{4}$ Despite this general declaration, the Court makes an exception for evidence obtained in violation of prohibition of torture, inhuman or degrading treatment or punishment, expressed in Article 3 ECHR. The case-law of the ECtHR concerning

3 Hereafter referred to as "ECtHR" or "the Court".

4 ECtHR judgment of 12th July 1988, Schenk v. Switzerland, appl. no. 10862/84, $\S 46$; ECtHR [Grand Chamber] judgment of 10th March 2009, Bykov v. Russia, appl. no. 4378/02, §§ 88-90. See also: HOFMAŃSKI, Piotr; WRÓBEL, Andrzej, Artykuł 6. In: GARLICKI Lech (org.). Konwencja o ochronie praw człowieka i podstawowych wolności. Tom I. Komentarz do artykułów 1-18, Warsaw: C.H. Beck Publishing, 2010. p. 338. 
the fairness of criminal proceedings that use evidence (explanations or testimonies) obtained by investigative authorities (public officials) in violation of the prohibition set forth in Article 3 ECHR is fairly abundant and relatively consistent. The ECtHR firmly and clearly holds that the use of statements extracted by torture or inhuman or degrading treatment invariably renders the proceedings unfair, regardless of the significance of the evidence for the determination of the facts in the case. ${ }^{5}$ In the case of Jalloh $v$. Germany, the Court proved the above thesis, arguing that "any other conclusion would only serve to legitimate indirectly the sort of morally reprehensible conduct which the authors of Article 3 of the Convention sought to proscribe or, as it was so well put in the United States Supreme Court's judgment in the Rochin case..., to 'afford brutality the cloak of law."” Only exceptionally, if the person subjected to treatment contrary to Article 3 ECHR remained silent during the interrogation (gave no statement), the Court considers charges under Article 6 ECHR inadmissible. Thus, the only reason for assessment of such a complaint brought under Article 6 ECHR as inadmissible is when the interrogated person failed to supply any evidence which could be used against him or her in the criminal proceedings. ${ }^{7}$

Statements obtained through foreign legal assistance for the use in the criminal proceedings will also render such proceedings unfair if the applicant proves a "real risk" of collecting the evidence in violation of Article 3 ECHR. ${ }^{8}$ That the ill-treatment affected a third party (a witness)

5 See, inter alia, ECtHR [Grand Chamber] judgment of 11th July 2006, Jalloh $v$. Germany, appl. no. 54810/00, §§ 99, 105; ECtHR [Grand Chamber] judgment of 1st June 2010, Gäfgen v. Germany, appl. no. 22978/05, § 166; ECtHR judgment of 11th February 2014, Cěsnieks v. Latvia, appl. no. 9278/06; §§ 65-66; ECtHR [Grand Chamber] judgment of 13th September 2016, Ibrahim and Others $v$. the United Kingdom, appl. nos. 50541/08, 50571/08, 50573/08 and 40351/09, § 254.

6 ECtHR judgment of Jalloh v. Germany, § 105.

7 ECtHR judgment of 15th October 2019, Mehmet Ali Eser v. Turkey, appl. no. 1399/07, §§ 41-42.

8 ECtHR judgment of 25th September 2012, El Haski v. Belgium, appl. no. 649/08, §§ 81-88. On this issue, see: WĄSEK-WIADEREK, Małgorzata, Model zakazów dowodowych z perspektywy Konwencji i orzecznictwa ETPCz. In: SKORUPKA Jerzy; DROZD Anna (org.). Nowe spojrzenie na model zakazów dowodowych w procesie karnym, C.H. Beck Publishing, Warsaw. 2015, p. 26-27. 
and not a defendant is irrelevant, so is the fact that illegal methods of interrogation were employed by officials from another country. ${ }^{9}$ Furthermore, the transfer (extradition or deportation) of an individual to another criminal jurisdiction for trial runs a risk of "flagrant denial of justice" and, therefore, violates Article 6 ECHR if there is a real possibility of the person being subjected to criminal proceedings that admit evidence obtained by torture or inhuman treatment. Who has been the source of the evidence is irrelevant. What is significant is the use of the method of interrogation contrary to Article 3 ECHR. ${ }^{10}$

The Court's stance on real evidence directly obtained through torture or inhuman or degrading treatment is less firm. There is no caselaw of the ECtHR on the admissibility of real evidence obtained directly through torture. However, in El-Haski v. Belgium case, the Court said, although only obiter dictum, that it should be assessed in the same manner as statements obtained under torture. ${ }^{11} \mathrm{~A}$ different standard seems to apply to real evidence obtained through other forms of ill-treatment. In the aforesaid case of Jalloh v. Germany, the Court held that the use of such evidence did not automatically render the criminal proceedings unfair in all circumstances. However, if this is the case, the Court is required to assess the fairness of the entire proceedings, taking into account the significance of the evidence to the facts, the defendant's ability to challenge its admissibility before the court, as well as the criterion of public interest in criminal prosecution. ${ }^{12}$ Likewise, criminal proceedings

9 THIENEL, Tobias. The admissibility of evidence obtained by torture under international law. European Journal of International Law, v. 17, n. 2, 2006, pp. 362-363.

10 See, ECtHR judgment of 12th February 2012, Othman (Abu Qatada) $v$. United Kingdom, appl. no. 8139/09, §§ 263-287; ECtHR judgment of 24th July 2014, Al-Nashiri v. Poland, appl. no. 28761/11, §§ 662-569; ECtHR judgment of 24th July 2014, Husayn (Abu Zubaydah) v. Poland, appl. no. $7511 / 13, \S \S 552-561$.

11 ECtHR judgment of 25th September 2012, El Haski v. Belgium, appl. no. $649 / 08, \S 85$.

12 ECtHR judgment of Jalloh v. Germany, $\S \S 105-108$; see also ECtHR judgment of 22 October 2020, Bokhonko v. Gorgia, appl. no. 6739/11, §§ 94-99 (in this case the main evidence - drugs were extracted from the applicant's rectum during the search constituting ill-treatment in accordance with the applicant's arguments). 
are not automatically deemed unfair because of the use of evidence collected indirectly through inhuman treatment (the so-called "fruits of the poisonous tree"). According to the Court, such a trial may be presumed unfair, yet such presumption may be challenged taking into account the specific circumstances of the case. ${ }^{13}$

All in all, with reference to statements obtained in violation of Article 3 ECHR directly by public functionaries, with their consent or permission, the European standard is unambiguous: irrespective of the procedural setup, the use of such evidence in a criminal trial, as well as exposing a person to proceedings in which such evidence can be made use of (for example, in case of extradition or expulsion), constitutes a violation of Article 6 ECHR.

Such an interpretation of Article 6 ECHR has much in common with the universal standard arising from Articles 1 and 15 of the UN Convention against Torture. ${ }^{14}$ The definition of torture provided therein makes clear references to acts "committed by or at the instigation of or with the consent or acquiescence of a public official or other person acting in an official capacity." The exclusionary rule expressed in Article 15 thereof prohibits the use as evidence of any statement made under torture in any proceedings, except against a person accused of torture as evidence that such a statement was made. However, the UN Convention does not refer this prohibition to evidence obtained as a result of less

13 ECtHR judgment of Gäfgen v. Germany, §§ 178-188. On the ambiguity of the case-law on this issue: JASIŃSKI, Wojciech; CHOJNIAK, Łukasz. The Admissibility of Evidence Obtained by Torture and Inhuman or Degrading Treatment in Criminal Proceedings. Overview of European and Polish Standards. In: FENYVESI, Csaba; HERKE Csongor (org.). Pleadings. Celebration Volume of Professor Tremmel Florian's 70th Birthday. 148 Studia Iuridica Auctoritate Universitatis Pecs Publicata I (2011). Pecs 2011. pp. 128-130. It is unclear whether this standard applies also to real evidence obtained indirectly through torture. The case-law does not answer the question whether the real evidence shall always be inadmissible, irrespective whether obtained directly or indirectly as a result of torture.

14 United Nations Convention against Torture and Other Cruel, Inhuman or Degrading Treatment or Punishment, adopted by General Assembly Resolution of 10 December 1984. Hereafter referred to as "the UN Convention" or "CAT". 
severe forms of ill-treatment, such as inhuman or degrading treatment. ${ }^{15}$ In this respect, the wording of the UN Convention differs from the soft-law 1975 UN Torture Declaration. ${ }^{16}$ Still, given the wording of sentence two of Article 16 the UN Convention, some authors argue that for the purposes of Article 15 of the same instrument, inhuman treatment should also be deemed equivalent to torture. This would mean that also statements forced through ill-treatment which is not torture are subject to the exclusionary rule contained in this provision. ${ }^{17}$ This view is not commonly supported in the literature. ${ }^{18}$

Like in the Strasbourg human rights protection system, the exclusionary rule set out in Article 15 CAT covers any statements obtained by torture, including those made by third persons (e.g. witnesses) and not only by defendants in criminal proceedings. Moreover, the exclusionary rule also concerns statements extracted in the same manner by public officials from another country. ${ }^{19}$ On the other hand, given the definition of torture contained in Article 1 of the UN Convention, the exclusionary rule

15 See, GRAFFIN, Neil J. The legal consequences of ill-treating Detainees held for Police Questioning in Breach of Article 3 ECHR. European Journal of Current Legal Issues, v. 20, n. 2, 2014, p. 4.

16 Declaration on the Protection of All Persons from Being Subjected to Torture and Other Cruel, Inhuman or Degrading Treatment or Punishment Adopted by General Assembly resolution 3452 (XXX) of 9th December 1975. Article 12 of the Declaration states that "Any statement which is established to have been made as a result of torture or other cruel, inhuman or degrading treatment or punishment may not be invoked as evidence against the person concerned or against any other person in any proceedings".

17 See opinions of the Committee Against Torture ("CAT") delivered in reporting procedure and referred to by PATTENDEN Rosemary. Admissibility in criminal proceedings of third party and real evidence obtained by methods prohibited by UNCAT. International Journal of Evidence and Proof, v. 10, n. 1. 2006, p. 8, footnote 62 .

18 As reported by Giuliana Monina, different approach is taken by CAT in an individual complaint procedure and this approach also prevails in academic literature. See: MONINA, Giuliana. Article 15. Non-Admissibility of Evidence Obtained by Torture. In: NOWAK, Manfred; BIRK Moritz; MONINA Giuliana (org.). The United Nations Convention Against Torture and Its Optional Protocol. A Commentary. Oxford University Press 2019. pp. 437.

19 THIENEL Tobias, op. cit., pp. 356, 360. 
under its Article 15 does not apply to the conduct of private individuals. Private acts of torture would not be excluded pursuant to this provision. ${ }^{20}$

Universal standard of protection of human rights is also created by International Covenant on Civil and Political Rights ${ }^{21}$. The ICCPR does not contain any general rules on admissibility of evidence. However, Article 14 para. 3 (g) of the ICCPR provides for the right not to be compelled to testify against himself or to confess guilt. Thus, forced statements of a defendant shall not be admissible evidence. Furthermore, the Human Rights Committee derives a similar exclusionary rule from Article 7 of the Covenant. It seems to cover not only statements obtained by torture but also by other forms of cruel treatment. ${ }^{22}$

In conclusion, the Strasbourg Court challenges the fairness of any proceedings which make evidentiary use of statements obtained by public officials, both as a result of torture and other forms of conduct prohibited under Article 3 ECHR, regardless of the relevance of such impugned evidence to the determination of the facts of the case. In this respect, the Strasbourg standard seems more rigorous than the universal one defined in the UN Convention, the latter applying the exclusionary rule directly and unequivocally only to statements forced by torture. The European standard covers also real evidence obtained directly or indirectly as a result of treatment contrary to Article 3 of the ECHR. However, the Court's approach to real evidence obtained by ill-treatment that is not sufficiently severe to qualify as torture is less strict. When examining such cases, the Court assesses the fairness of the proceedings as a whole.

20 SCHARF, Michael P. Tainted Provenance: When, If Ever, Should Torture Evidence Be Admissible?, Case Research Paper Series in Legal Studies. Working Paper 07-27, September 2007, p. 21.

21 International Covenant on Civil and Political Rights adopted by United Nations General Assembly on 16 December 1966. Thereafter referred to as "ICCPR".

22 GENERAL COMMENT NO. 20: ARTICLE 7 (PROHIBITION OF TORTURE OR OTHER CRUEL, INHUMAN OR DEGRADING TREATMENT OR PUNISHMENT) adopted at the forty-fourth session (1992), para. 12; GENERAL COMMENT NO. 32, ARTICLE 14: RIGHT TO EQUALITY BEFORE COURTS AND TRIBUNALS AND TO A FAIR TRIAL), adopted at the ninetieth session, (2007), CCPR/C/GC/32. 


\section{AdMISSIBILITY OF EVIDENCE OBTAINED BY PRIVATE INDIVIDUALS APPLYING METHOdS CONTRARY TO ARTICLE 3 ECHR.}

The procedures of some European countries allow fact-finding in a criminal trial based on the so-called private evidence, meaning documents, statements, or recordings made by private individuals outside criminal proceedings. Sometimes only "private" evidence gathered outside a criminal trial and for purposes other than the trial can be admitted. ${ }^{23}$ Some jurisdictions, including Poland, permit evidentiary use of information, e.g. recordings, collected by private individuals with the intention of using it later in criminal proceedings. ${ }^{24}$ Given the foregoing, the question posed in the title of this paper should be asked, namely whether the Strasbourg standards of fair trial allow the use in criminal proceedings of private evidence collected by methods violating the prohibition defined in Article 3 ECHR. Apparently, in order to provide the correct answer to this question two situations need to be distinguished. First, the use in a criminal trial of the so-called "find," i.e. a piece of evidence, such as a recording containing statements extracted by torture or inhuman treatment, however, produced entirely without any connection with the trial, outside the trial, and for purposes other than the trial; and, second, the use in a criminal proceedings of information (recordings of statements) obtained by private individuals applying similar methods as those named above but with the intention of using them in the trial.

23 Article $393 \S 3$ of the Polish Code of Criminal Procedure as applicable until 30th June 2015 stated that "All private documents prepared outside of the criminal proceedings and not for their purpose, including statements, publications, letters and notes, may be read out at the trial".

The current wording of Article $393 \S 3$ of the CCP reads as follows: "All private documents drawn up outside criminal proceedings, including statements, publications, letters and notes, may be read out at the trial". However, due to ambiguous wording of Article 168a of the Code of Criminal Procedure, it is not clear whether this provision applies fully to private evidence obtained as a result of serious criminal acts. See: SOLODOV, Denis; SOLODOV, Ilia. Legal safeguards against involuntary criminal confessions in Poland and Russia. Revista Brasileira de Direito Processual Penal, Porto Alegre, vol. 6, n. 3, pp. 1673-1676. On admissibility of private evidence in selected European countries, see: BOJAŃCZYK, Antoni. Dowód prywatny w postępowaniu karnym w perspektywie prawnoporównawczej. Warsaw: Wolters Kluwer Publisher, 2011. pp. 21-177. 


\subsection{Judgement in ĆWik v. Poland}

Until November 2020, this problem had not been solved in the European system of protection of human rights. Yet, based on some comments by the Council of Europe Commissioner for Human Rights or the Secretary General of the Council of Europe, they can be said to incline towards inadmissibility of evidence obtained using methods contrary to Article 3 ECHR, regardless of who has employed the prohibited methods. ${ }^{25}$ A review of the dissenting opinions of ECtHR judges to the Grand Chamber's judgment on the absence of violation of Article 6 ECHR in the case of Gäfgen v. Germany leads to a similar conclusion. ${ }^{26}$

The issue in question has been recently decided for the first time in the case of Ćwik v. Poland. ${ }^{27}$ The domestic court determined the facts of the case, inter alia, on the basis of a recorded "interrogation" of K.G. who, together with the applicant, had engaged in the unlawful practice of smuggling cocaine from the USA to Poland. K.G. and the applicant had come into conflict with other members of their organized crime group. That led to K.G.'s abduction by the other members of the group and torturing him to elicit information on the location of the smuggled cocaine and cash. In the course of K.G.s' "interrogation" carried out in the presence of, but not only, the leader of the criminal group, A.H., and a M.W., and recorded at the instruction of L.P., K.G. disclosed the place where the cocaine and the cash had been concealed. K.G. was later released from the abductors by the police, who also secured the recording. The recording was then used as evidence in the criminal proceedings conducted against the applicant (Ćwik), who pleaded not guilty and refused to give explanations during the trial. The domestic court determined the facts on the basis of various pieces of evidence, including the testimony

25 See: Comments by the Council of Europe Commissioner for Human Rights and the Secretary General of the Council of Europe referred to in: PATTENDEN, Rosemary. Admissibility in criminal proceedings of third party and real evidence obtained by methods prohibited by UNCAT. International Journal of Evidence and Proof, v. 10, n. 1. 2006. p. 12.

26 ECtHR judgment, Gäfgen v. Germany: joint partly dissenting opinion of judges Rozakis, Tulkens, Jebens, Ziemele, Bianku and Power, in particular para. 2 of the opinion

27 ECtHR judgment of 5th November 2020, Ćwik v. Poland, appl. no. 31454/10. 
of L.P. and M.W. "interrogating” K.G., as well as on a transcript of the recording, which, in the opinion of the court, constituted "an important item of evidence confirming the credibility of L.P. and M.W. with regard to K.G.'s and the applicant's involvement in the cocaine business, as well as confirming the applicant's guilt". ${ }^{28}$ In the course of the criminal proceedings against the applicant, K.G. was not heard because he was hiding and his whereabouts could not be established. The domestic court which examined the appeal and the applicant's pleas against evidentiary use of the recording of K.G.'s "interrogation" held that the exclusion of statements extracted by torture, as set forth in Article $171 \S 7$ of the Code of Criminal Procedure, ${ }^{29}$ did not apply if coercive interrogation, as in the examined case, was conducted by private individuals. ${ }^{30}$ At this point, it needs to be clarified that in accordance with the Polish law applicable at the time, it was permitted to disclose during the trial all private documents produced outside the criminal proceedings and not for the purpose of those proceedings.

In that case, the ECtHR found a violation of Article 6 para. 1 ECHR and stated, simply put, that the current case-law standard, as discussed elsewhere in this paper, should also be applied to "private evidence." Before moving on to assessing the Court's view, it should be stressed that this judgment was delivered by the Chamber of the ECtHR. The Polish government did not avail itself of the opportunity to appeal against the judgment to the Grand Chamber of the ECtHR. Consequently, it became final on 5 February 2021. The judgment was handed down with a majority of 5:2 votes. Of course, the sole fact of majority voting does not undermine

28 ECtHR judgment, Ćwik v. Poland, § 23.

29 This provision clearly states that "Explanations, testimonies and statements made in circumstances precluding freedom of speech or obtained against the prohibitions mentioned in $\S 5$ [i.e. prohibition to influence statements of a testifying person by means of force or illicit threat], may not constitute evidence".

${ }^{30}$ Such interpretation of this provision was also presented in legal literature: JASIŃSKI, Wojciech. Nielegalnie uzyskane dowody w procesie karnym. W poszukiwaniu optymalnego rozwiązania. Wolters Kluwer Publishing, Warsaw 2019. pp. 581-582; RUSINEK, Michał. Zakazy odnoszące się do sposobu dowodzenia. In: SKORUPKA Jerzy (org.) System Prawa Karnego Procesowego. Dowody. Tom VIII, cz. 2, Wolters Kluwer Publisher. Warsaw 2019. p. 2229. 
the solidity of the judgment. However, it proves the discrepancy of views of Strasbourg judges on this extremely difficult problem. Despite strong arguments put forward in the judgment, it can hardly be regarded as determining and clarifying, in a firm and exhaustive manner, the standard on the admissibility of "private evidence". The position of the majority of the Court's judges seems to neglect certain vital arguments in favor of the opposite view. Regrettably, the joint dissenting opinion of the two judges who voted against ascertaining the violation of Article 6 para. 1 ECHR in this case does not exhaust the argumentation, although it does outline the normative context behind their decision more broadly.

The very essence of the Court's opinion is expressed in Section 89 of the judgement where the Court finds that the principle established in the case-law on the inadmissibility of statements extracted by a public official using methods contrary to Article 3 ECHR "is equally applicable to the admission of evidence obtained from a third party as a result of ill-treatment proscribed by Article 3 when such ill-treatment was inflicted by private individuals, irrespective of the classification of that treatment". In the opinion of the Court, the domestic court failed to consider the fact that the evidence had been obtained in violation of the absolute prohibition. In the judgment, the Court emphasized that the protection against conduct proscribed under Article 3 ECHR is the state's positive obligation, also when inflicted by private individuals. This assertion was supported by reference to multiple rulings on the state's positive obligations, including procedural ones, arising from Article 3 ECHR. ${ }^{31}$

Furthermore, the Court underlined that evidence obtained under torture should be excluded "to protect the integrity of the trial process, and, ultimately, the rule of law itself". Quoting the Othman (Abu Qatada) $v$. The United Kingdom case, the ECtHR stated that "no legal system based on the rule of law can countenance the admission of evidence - however reliable - which has been obtained by such a barbaric practice as torture" and that "torture damages irreparably the trial process". ${ }^{32}$

All in all, the ECtHR refrained even from verifying the legitimacy of the other applicant's complaint in respect to the fairness of his trial,

\footnotetext{
31 ECtHR judgment Ćwik v. Poland, §§ 63-67.

32 ECtHR judgment Ćwik v. Poland, $\S 74$.
} 
i.e. one concerning failure to examine K.G., the victim of the torture, in the course of the proceedings. In the Court's view, the very admission of the impugned transcript into evidence in the criminal proceedings against the applicant rendered the proceedings as a whole unfair, in breach of Article 6 para. 1 ECHR. ${ }^{33}$

Meanwhile, the dissenting judges referred to the definition of torture contained in Article 1 of the UN Convention, stressing that the exclusionary rule under Article 15 of the Convention applies only to acts which can be directly or indirectly attributed to public officials. Accordingly, it does not concern acts performed by private individuals. The dissenting judges also made references to the provisions of the Rome Statute of the ICC, which do not automatically exclude evidence obtained in violation of "internationally recognized human rights", since their inadmissibility depends on whether (a) the violation casts substantial doubt on the reliability of the evidence; or (b) the admission of the evidence would be antithetical to and would seriously damage the integrity of the proceedings (Article 69.7 of the Rome Statute of the ICC).

The dissenting opinion also highlights that restrictions of admissibility of evidence are an exception, hence they require a detailed justification, which, as a rule, is not needed for admission of evidence. Judges Wojtyczek and Pejchal also emphasized the significance of the principle of free assessment of evidence and linked it to the principle of free admission of evidence. Finally, both dissenting judges concluded that there were no grounds for the application of the same standards to evidence obtained through ill-treatment by private individuals and to evidence obtained by public officials. They supported this thesis by two arguments. First, for evidence obtained by public officials in violation of Article $3 \mathrm{ECHR}$, the risk of the unfairness of the proceedings comes from the possibility of using evidence which is false or fabricated. Such risk does not exist when the evidence is gathered without any involvement of public authorities. Second, unlike in case of applying exclusionary rule to tainted evidence produced by public officials, the extension of this rule to "private evidence" obtained in similar circumstances does not reinforce the protection against ill-treatment. Thus, "the acceptance of evidence

33 ECtHR judgment Ćwik v. Poland, §§ 91-93. 
like that in question in the instant case does not encourage torture by private parties". ${ }^{34}$ In addition, the judges stressed that the case should be approached differently if the recording had been used in the criminal proceedings against K.G. Due to protection of the right to remain silent, this type of evidence should be considered inadmissible.

\subsection{Critical remarks to the judgment of the ECthR in Ćwik v. Poland}

The position expressed by the ECtHR in the case can hardly be shared. In general, the view of dissenting judges should be endorsed. However, as pointed out elsewhere, both the view expressed by the majority of the Court as well as the position formulated in the dissenting opinion do not seem to make allowances for all arguments and circumstances which should be considered when establishing a standard for fair criminal proceedings in which a private recording of statements extracted by torture or inhuman treatment was admitted as evidence.

The majority who voted in favor of the violation of Article 6 ECHR did not attach sufficient importance to the fact that the recording had objectively existed before the proceedings against the applicant were instigated and was not used in proceedings against the person subjected to torture. The recording had been made outside of the criminal proceedings and not for the purpose thereof. Moreover, and crucially, it was produced without any connection with the activities of public officials. Obviously, the prohibition of torture is unquestionable and constitutes a mandatory rule (ius cogens) of international law. In other words, it is absolute and cannot be derogated from. ${ }^{35}$ The status of ius cogens is sometimes also conferred on the exclusionary rule contained in Article 15 of the UN Convention, ${ }^{36}$ although the question remains controversial. At the same

${ }^{34}$ ECtHR judgment Ćwik v. Poland, § 12 of the dissenting opinion.

35 See, however, a discussion on its scope and attempts to find some arguments against the absoluteness of this prohibition in certain, exceptional circumstances - a discussion following Gäfgen v. Germany judgment: GREER, Steven. Is the Prohibition against Torture, Cruel, Inhuman and Degrading Treatment Really 'Absolute' in International Human Rights Law? Human Rights Law Review 2015. pp. 1-37. (advance access published on January 30, 2015).

36 See, PATTENDEN, Rosemary. Admissibility in criminal proceedings of third party and real evidence obtained by methods prohibited by UNCAT. 
time, the universal definition of torture in the UN Convention is linked to acts, or at least the acquiesce, of public officials or other person acting in an official capacity.

The main argument put forward in the Ćwik v. Poland judgment was that "torture evidence" devastates the integrity of the trial process and, consequently, the rule of law itself. This view, expressed in the Othman (Abu Qatada) v. the United Kingdom case, deserves full support. However, in this case, it was applied by the ECtHR to evidence obtained as a result of treatment defined as torture in Article 1 of the UN Convention Against Torture (CAT), i.e. treatment "inflicted by or at the instigation of or with the consent or acquiescence of a public official or other person acting in an official capacity". As clearly transpires from paragraph 266 of the Othman (Abu Qatada) v. the United Kingdom judgment, the Court found support for its reasoning in Article 15 CAT, which, no doubts, applies only to evidence obtained by torture as defined in Article 1 of this Convention. Moreover, in this case, the applicant's deportation could be assessed as silent acceptance of the known and widely applied practice of torture administered by Jordanian public officials towards witnesses and defendants in criminal proceedings. It would mean the tolerance for intentional ill-treatment inflicted by state officials for the purpose of gathering evidence to be used in the trial.

Unfortunately, in Ćwik v. Poland one cannot find convincing arguments why the same exclusionary rule shall be automatically applied to a private recording produced by members of the organized crime without any intention to use it as evidence in the future criminal proceedings while such a recording was found by chance by the police. Relying solely on the ius cogens character of torture prohibition is not sufficient here since in international law it relates to torture as defined by Article 1 CAT. Thus, the only convincing argument could be based on the standard of positive

International Journal of Evidence and Proof, v. 10, n. 1. 2006. p. 8, and the decision of the Committee Against Torture referred to therein: COMMITTEE AGAINST TORTURE decision of 21 November 2002, P.E. v. France, Comm. No. 193/2001, U.N. Doc. A/58/44, at 135 (CAT 2002), para. 6.3.; See, however, the opposite view: SCHARF, Michael P. Tainted Provenance: When, If Ever, Should Torture Evidence Be Admissible?, Case Research Paper Series in Legal Studies. Working Paper 07-27, September 2007. pp. 23-24. 
obligations of state-parties of the ECHR to provide effective protection against all forms of ill-treatment, including those administrated by private individuals. However, as will be argued further on, admission of the said recording as evidence in criminal proceedings cannot be assessed as an act of tolerance for ill-treatment inflicted between private individuals.

In its judgment in Ćwik v. Poland, the Court rightly emphasized that the prohibition set forth in Article 3 ECHR had previously been referred in the case-law not only to public officials but also to private individuals. Particularly, in cases concerning extradition or expulsion, the Court examines whether transferring a person to another jurisdiction may expose him or her to a real risk of maltreatment by private persons. ${ }^{37}$ Therefore, states parties to the ECHR are not only obliged to refrain from conduct referred to in Article 3 ECHR but also take positive measures to protect persons subject to their jurisdictions from ill-treatment, as well as by other private individuals. ${ }^{38}$ The scope of the state's positive obligations is not only confined to prevention but also covers an appropriate procedural response to ill-treatment of a private person by another ${ }^{39}$ Such obligations are met by the implementation of effective prosecution of such conduct. States must also evolve their legal systems in a way that does not foster tolerance of private persons' conduct contrary to Article 3 ECHR. ${ }^{40}$

37 See, in particular, ECtHR [Grand Chamber] judgment of 29 April 1997, H.L.R. v. France, appl. no. 24573/94, § 33-44. In this case the risk of the applicant's ill-treatment, if deported to Colombia, emanated from drug traffickers. The Court did not find a violation of Article 3 of the Convention since in its opinion no real risk of ill-treatment was established. See also the judgment of the ECtHR of 16th June 2016, R.D. v. France, appl. no. 34648/14, §§ 43-45.

38 See, inter alia, ECtHR judgment of 31st May 2007, Šečić v. Croatia, appl. no. 40116/02, §53. Protection from ill-treatment administrated by private actors is also considered as part of "positive obligations" stemming from Article 16 of the CAT. Failure to act by the police officers, although they had been informed of the immediate risk of ill-treatment that a person was facing, is implying 'acquiescence' within the meaning of Article 16 of the Convention: COMMITTEE AGAINST TORTURE decision of 21 November 2002, Hajrizi Dzemajl et al. v. Yugoslavia, Comm. No. 161/2000, U.N. Doc. CAT/C/29/D/161/2000 (2002), para. 9.2.

39 See inter alia ECtHR judgment of 25th June 2009, Beganović v. Croatia, appl. no. 46423/06, $\S \S 66$ and 69.

40 ECtHR judgment of 23rd September 1998, A. v. UK, appl. no. 25599/94, § 22. 
In the context of the case-law at hand, a question arises of whether the use of evidence obtained outside criminal proceedings (prior to their instigating) by private individuals as a result of ill-treatment may be perceived as the establishment by the state of a legal framework for tolerating the collection of evidence by private individuals in violation of Article 3 ECHR, and thus for tolerating such conduct in general. Before responding to this question, however, it should be noted that the situation discussed above should not be treated on a par with exposure of a person to ill-treatment by private individuals as a result of handing that person over to another jurisdiction (country). Should this be the case, the state party to the ECHR has the means to prevent the real and prospective illtreatment. In contrast, if the investigative or judicial authorities obtain already existing evidence containing a recorded statement by a person subjected to ill-treatment, the implications are quite different: the state has no possibility of preventing a violation of Article 3 of the Convention; it may merely fulfil its positive obligation to prosecute the torturer.

Returning to the obligation to develop a legal system that does not foster tolerance of conduct violating Article 3 ECHR, the following conclusions must be drawn. It seems that tolerance of ill-treatment would occur if domestic law allowed admission of private evidence collected through such treatment for the purpose of criminal proceedings, i.e. when private individuals act intentionally to make evidentiary use of statements obtained through inflicting violence. In the author's view, inadmissibility of such evidence in a criminal trial can be justified on grounds of Article 3 ECHR. The opposing view that the exclusionary rule applies exclusively to evidence obtained by public officials would lead to an unacceptable conclusion that the investigative and judicial authorities may acquiesce to or tolerate the methods of collecting private evidence in violation of Article 3 ECHR in order to use the evidence later on in criminal proceedings as authorized by a competent judicial body. To cite a metaphor used in the judgment Jalloh $v$. Germany, in this way brutality would be afforded "the cloak of law" by the judicial authority (the court) which admitted the evidence, being aware that probative statements had been extracted in a disgraceful manner just for the purpose of the criminal trial. The admission of such evidence in the criminal trial could be compared to the "acquiescence of a public official" within Article 1 of the UN Convention 
against Torture. In the case in question, the acquiescence would come from the court admitting the statements extracted in such a manner for the purposes of the trial. This would stand in contradiction with the state party's obligation of taking positive action to protect persons from treatment violating Article 3 ECHR and suffered from private individuals.

What raises doubts, however, is the position contained in the judgment in the case of Ćwik $v$. Poland, demanding the same approach to a situation when a tainted evidence (recording of statements) is produced outside the criminal proceedings, before its initiation, and, more importantly, for other purposes. The recording referred to in the case was a typical "find." It had objectively existed before the launch of the criminal proceedings against the applicant Grzegorz Ćwik; it had been secured in the course of lawful action of the Police (search); and its use in the criminal trial could not in any way reduce K.G.'s protection against torture or inhuman treatment. On the other hand, as rightly noted in the dissenting opinion accompanying the judgment, refusal to use this evidence in the trial could not have enhanced K.G.'s protection from inhuman or degrading treatment by the members of the criminal group who "interrogated" him. At the same time, one should bear in mind that the admission of the recording as evidence in the criminal proceedings increased chances of effective prosecution of organized crime. As follows from the Court's judgement, the torturers identified in the recording were prosecuted in another criminal proceedings, which needs to be considered an adequate procedural response and the fulfilment of Poland's positive obligations towards K.G. arising from Article 3 of the Convention.

However, arguments expressed in the Court's justification of the judgment deserve one more critical remark. The Court combined the question of the admissibility of evidence with the assessment of its reliability. This approach, also adopted in many other rulings of the ECtHR, is at least debatable. The assessment of the admissibility of evidence is performed a priori; in Poland and some European countries it is formal in character. It should not entail the examination of the reliability of evidence. If the two areas are mixed (admissibility of evidence and assessment of the reliability of evidence), it may have an adverse effect on the procedural rights of the parties, which should naturally participate in the taking of evidence admitted in the trial and should be able to either 
challenge or support its reliability at this procedural stage.$^{41}$ Still, in some legal systems, the stage of admission of evidence is non-adversarial, meaning that it is based on the judicial authority recognizing or rejecting a motion of evidence, frequently in a written form and outside the public hearing. Meanwhile, the justification of the judgement in Ćwik v. Poland, especially Section 74, leads to the conclusion that in the opinion of the ECtHR the recording of "private torture" must be excluded as evidence because it is unreliable. The ECtHR stated that the use of such evidence automatically makes the criminal proceedings against the applicant unfair without taking into consideration whether other evidence admitted by the domestic court was fully legal and sufficient for justifying the applicant's conviction. In effect, if the exclusion of tainted evidence from the trial, as argued elsewhere, may not, in any case increase protection of the author of the recorded statements from ill-treatment, and the important argument for inadmissibility of this evidence is its unreliability, then the domestic court was right to consider it admissible and proceed with the assessment of its reliability. It should be underlined that the ECtHR does not lose the possibility of reviewing the fairness of the criminal proceedings due to the fact that the conviction was based on evidence declared admissible but, at the same time, obtained in circumstances jeopardising its reliability. In numerous cases in which the guilt of the sentenced person was established on the basis of testimonies of crown witnesses or incognito depositions, the Court did not focus on the admissibility of evidence but merely indicated the necessity of a careful, thorough examination of such depositions, taking into account their unique character, as well as their importance for fact-finding. ${ }^{42}$ Such an approach, known as "the

41 This aspect is rightly noticed in: JASIŃSKI, Wojciech. Nielegalnie uzyskane dowody w procesie karnym. W poszukiwaniu optymalnego rozwiązania. Wolters Kluwer Publishing, Warsaw 2019. p. 170. Of course, this problem does not exist if the national law unequivocally prohibits admission of evidence collected in violation of the law.

42 ECtHR decision of 25th May 2004, Arnold G. Cornelis $v$. the Netherlands, appl. no. 994/03 (with reference to the use of testimony of a witness granted immunity); ECtHR judgment of 11th February 2002, Visser $v$. the Netherlands, appl. no. 26668/95, §§ 43-52 (with reference to the statement of an anonymous witness). However, this approach was also criticized in the literature: TRECHSEL, Stefan; SUMMERS, Sarah, J. Human Rights in Criminal Proceedings, Oxford University Press, Oxford 2006. p. 313. 
sole or decisive rule", is frequently applied by the Court not only in cases involving anonymous witnesses or crown witnesses but also with reference to untested evidence (hearsay witnesses). With regard to this type of evidence, it is underlined by the ECtHR that "its admission will not automatically result in a breach of Article $6 \S 1$ [of the Convention]. At the same time, where a conviction is based solely or decisively on the evidence of absent witnesses, the Court must subject the proceedings to the most searching scrutiny." ${ }^{43}$ Therefore sufficient counterbalancing factors should be in place, including measures that permit a fair and proper assessment of the reliability of that evidence ${ }^{44}$.

A similar holistic approach is also applied to evidence obtained in breach of respect for private life. When called upon to assess the case in which a secret recording gathered in the course of a covert operation was admitted as evidence, the Court did not focus on its admissibility but on the fairness of the proceedings as a whole. The ECtHR underlined the necessity to examine "whether the applicant was given the opportunity of challenging the authenticity of the evidence and of opposing its use". ${ }^{45}$ Furthermore, it emphasized that "the quality of the evidence must be taken into consideration, including whether the circumstances in which it was obtained cast doubt on its reliability or accuracy." 46

Finally, what is of crucial importance here, the standard of "general assessment of fairness", although with extreme caution, is also applied by the ECtHR to cases in which domestic courts relied on real evidence obtained by inhuman or degrading treatment ${ }^{47}$ as well as

43 ECtHR judgment of 15 December 2011, Al-Khawaja and Tahery $v$. The United Kingdom, appl. nos. 26766/05 and 22228/06, § 147.

44 Ibidem.

45 ECtHR [Grand Chamber] judgment of 10th March 2009, Bykov v. Russia, appl. no. 4378/02, § 90. The same approach was applied in many subsequent cases. See, for instance: ECtHR judgment of 3 March 2016, Prade v. Germany, appl. no. 7215/10, §§ 33-35; ECtHR judgment of 5 December 2019, Hambardzumyan v. Armenia, appl. no. 43478/11, §§ 75-77.

46 Ibidem.

47 ECtHR judgment Jalloh v. Germany, $\S \S 106-107$. The ECtHR stated: "It cannot be excluded that on the facts of a particular case the use of evidence obtained by intentional acts of ill-treatment not amounting to torture will render the trial against the victim unfair, irrespective of the seriousness of the offence 
on real evidence gathered thanks to the statements forced by inhuman treatment of an interrogated suspect. ${ }^{48}$

Looking again at the circumstances of the case of Ćwik v. Poland, it should be concluded that since the evidentiary use of the recording could not have had any impact on K.G.'s protection from torture or any other forms of ill-treatment, emphasis should have been laid on the assessment of the fairness of the proceedings as a whole. After all, the transcript of the recording admitted in evidence was intended to corroborate the testimonies of the members of the criminal group who had been involved in the recorded "interrogation," and K.G. was not heard in the course of the proceedings. Accordingly, the key issue in the light of Article 6 ECHR was not the admission of the evidence but rather the review of the fairness of the criminal proceedings as a whole, also in view of the manner in which the domestic court assessed the evidence in the form of a transcript of the recording and its relevance to the determination of the facts.

To sum up, the automatic application of the exclusionary rule concerning statements extracted by ill-treatment by public officials to evidence obtained in similar circumstances by private individuals for purposes other than criminal proceedings is not substantiated by the necessity to respect the standard set by Article 3 ECHR. Moreover, if such evidence is used in proceedings against a third party, not being subjected to ill-treatment (like in Ćwik v. Poland case), its admissibility cannot be questioned by invoking the protection of a defendant against selfincrimination and his or her right to silence. This position does not limit the Court's competence to examine compliance of criminal proceedings with the requirements of a fair trial. The Court should examine the fairness of the proceedings as a whole, with particular emphasis laid on

allegedly committed, the weight attached to the evidence and the opportunities which the victim had to challenge its admission and use at his trial. [...]. In the present case, the general question whether the use of evidence obtained by an act qualified as inhuman and degrading treatment automatically renders a trial unfair can be left open." Fair Trial Rationale for Excluding Wrongfully Obtained Evidence, In: GLESS Sabine; RICHTER Thomas (org.). Do Exclusionary Rules Ensure a Fair Trial? A Comparative Perspective on Evidentiary Rules. Ius Gentium: Comparative Perspectives on Law and Justice 74. Springer Open, pp. 285-288. 
the reliability of admitted "private evidence" and its role in establishing the circumstances of the case.

Nevertheless, the above assertion does not lead to the overall approval of arguments put forward in the dissenting opinion. First, it appears to reinforce the conviction that the universal standard arising from Articles 1 and 15 of the UN Convention, as well as from the Rome Statute of the International Criminal Court (ICC), is the one which should have a limiting effect on the development of the European standard of a fair trial in terms of admission of evidence obtained as a result of illtreatment. In fact, even though the Court should interpret the ECHR with regard to universal standards, in the view of the lack of a legal definition of torture in the conventions of the Council of Europe, the Court is entitled to assume a higher level of protection against ill-treatment than the one set in the universal human rights protection system. As already mentioned, even a cursory analysis of the ECtHR's judgments in terms of state's positive obligations to ensure protection against ill-treatment leads to a conclusion that the relevant Strasbourg standard is currently stricter and, in the specific circumstances described above, may be directly applied to acts of private individuals as well. Consequently, the idea expressed in the dissenting opinion that the scope of the prohibition of torture does not go beyond the provisions of the UN Convention, ${ }^{49}$ seems to question the existing trend in the case-law of the ECtHR. ${ }^{50}$ Therefore, considering this standard of case-law, I believe that in specific circumstances, i.e. when private individuals ill-treat a person to illicit statements with the intention to subsequently use them in a criminal trial, the exclusionary rule discussed in the first part of this paper should apply.

On the other hand, it is worth noting that the liability of the state for torture inflicted by private individuals is also applicable to a limited extent under the UN Convention. This is the case when such acts are committed "with the consent or acquiescence of a public official or other person acting in an official capacity." ${ }^{51}$ The authors of the dissenting

49 ECtHR judgment Ćwik v. Poland, § 4 of the dissenting opinion.

50 See ECtHR judgments indicated in footnotes 37-40.

51 For interpretation of this term, see: ZACH, Gerrit. Article 1. Definition of Torture. In: NOWAK, Manfred; BIRK Moritz; MONINA Giuliana (org.). The 
opinion highlighted it in the last paragraph of Section 9 thereof. They find that even if the acquiescence to torture could be expressed ex post facto, this type of acquiescence did not occur in the examined case. This opinion is by far correct, yet at the same time, it supports the idea that the acts of private persons in violation of Article 3 ECHR (and simultaneously aimed to obtain admissible evidence for the purpose of a criminal trial) may be considered in terms of the creation of a legal framework that does not guarantee adequate protection against ill-treatment in this respect.

Reference to a ruling of the Extraordinary Chambers in the Courts of Cambodia (ECHCC) ${ }^{52}$ in the dissenting opinion is not fully convincing, either. It is necessary to keep in mind the context of the line of thought contained in the decision of the ECHCC. By relying on teleological interpretation, the ECHCC argued for a broader understanding of the exception from the exclusionary rule contained in the last sentence of Article 15 of the UN Convention. Yet, its intention was to enable broader use of evidence forced by torture in the proceedings against persons accused of the torture. Thus, the reason to apply such an interpretation was to allow more effective prosecution of the torturers. ${ }^{53}$ Still, even this approach was met with criticism..$^{54}$ In this context, the cited $\S 75$ of the ECHCC’s decision can hardly be recognized as supporting the dissenting opinion.

It is also noteworthy that, when recalling applicable international standards, the dissenting judges pointed to a rather general exclusionary rule expressed in Article 69.7 of the Rome Statute of the ICC, which does

United Nations Convention Against Torture and Its Optional Protocol. A Commentary. Oxford University Press 2019. pp. 61-62.

52 Thereafter referred to as "ECHCC".

53 ECHCC (TRIAL CHAMBER) decision of 5th February 2016, case no. 002/1909-2007/ECCC/TC. $\S \S 71-78$. See also attempts to find a flexible interpretation to the exception to the exclusionary rule in order to make prosecution of perpetrators of torture and their superiors more effective: SCHARF, Michael P. Tainted Provenance: When, If Ever, Should Torture Evidence Be Admissible?, Case Research Paper Series in Legal Studies. Working Paper 07-27, September 2007. pp. 19-27. Torture. In: NOWAK, Manfred; BIRK Moritz; MONINA Giuliana (org.). The United Nations Convention Against Torture and Its Optional Protocol. A Commentary. Oxford University Press 2019. pp. 439-440. 
not imply the automatic inadmissibility of evidence obtained in violation of internationally recognized human rights. However, at least the doctrine finds that the content of this provision determines that statements forced by torture or other forms of cruel treatment are inadmissible. ${ }^{55}$ Note that the definition of torture contained in Article 7.2(e) of the Rome Statute of the ICC does not imply that this kind of treatment occurs only if inflicted by a public official or at his or her consent. However, the substantive definition of torture is determined by the scope of the ICC's personal jurisdiction. ${ }^{56}$

The remaining arguments advanced in the dissenting opinion are worthy of approval. They refer to the circumstances of the case, i.e. to the fact that this was a piece of private evidence in the form of recorded statements obtained through inhuman treatment, albeit outside of and for purposes other than the criminal proceedings. The dissenting judges did not analyze any other situation discussed in this paper, namely the forcing of evidence by private individuals with the intention to subsequently use it in criminal proceedings, since such circumstances did not occur in the case of Ćwik v. Poland. Nevertheless, the firm assertion that the definition of torture does not go beyond the provisions of the CAT permits a conclusion that the dissenting judges do not extend the exclusionary rule to acts of private individuals, regardless of the circumstances and the purpose for which the evidence was obtained. This interpretation of the dissenting opinion is further supported by the judges' search for grounds for non-admission of evidence forced by "private torture" in the proceedings against the tortured person in the general obligation to respect the right of protection against self-incrimination rather than in the prohibition contained in Article 3 ECHR. ${ }^{57}$

55 KUCZYŃSKA, Hanna. Prawo dowodowe w postępowaniu przed Międzynarodowym Trybunałem Karnym. In: SKORUPKA Jerzy (org.) System Prawa Karnego Procesowego. Dowody. Tom VIII, cz. 2, Wolters Kluwer Publisher. Warsaw 2019. pp. 1727-1728.

56 PATTENDEN, Rosemary. Admissibility in criminal proceedings of third party and real evidence obtained by methods prohibited by UNCAT. International Journal of Evidence and Proof, v. 10, n. 1. 2006. pp. 9-10.

57 ECtHR judgment of Ćwik v. Poland, $\S 12$ of the dissenting opinion. It states as follows: "In any event, protection against self-incrimination does not justify per se a general exclusionary rule disqualifying evidence obtained through 


\section{Conclusions}

Undoubtedly, the ECtHR judgment in the case of Ćwik v. Poland will mark the beginning of a new chapter in the discussion of the European standard that should apply to admission in criminal proceedings as evidence of statements forced by torture or inhuman or degrading treatment by private individuals. Although the position of the Court is unambiguous, one may not overlook the solid arguments expressed in the dissenting opinion. It seems that this was precisely the case in the studied judgment. The majority in favor of the violation of Article 6 para. 1 ECHR failed to consider all possible aspects of obtaining the evidence. Therefore, it seems reasonable to find that the pertinent European standard in this area is in statu nascendi.

The article adopts a critical view of the judgment of the ECtHR. The Court did not attach adequate importance to the fact that the recording of "private torture", used as evidence in the domestic proceedings, had been made outside of and for purposes other than the criminal proceedings. Furthermore, it was admitted into criminal proceedings conducted against a third person, not against the victim of torture. In my view, these circumstances should render such evidence admissible. Consequently, the Court should not have questioned its admissibility but rather assessed the fairness of the criminal proceedings as a whole, also taking into account (i) the extent to which the defendant had been able to challenge the reliability of the evidence (the transcript of the recording to be precise), (ii) whether the domestic court had examined the evidence with reasonable care and (iii) what the role of the evidence was in fact-finding. The Court was in a position to make full use of wellestablished case-law concerning the assessment of the fairness of the criminal proceedings in which untenable evidence had been used, i.e. "the sole or decisive evidence doctrine."

However, evidence obtained through "private torture" or other forms of ill-treatment, i.e. collected by the same vile methods by private individuals, albeit for the purpose of criminal proceedings, should be

ill-treatment of one person, if this evidence is to be used in proceedings against another person." 
treated differently. In my view, this different approach is necessitated by the requirement of the state to meet its positive obligations pursuant to Article 3 ECHR.

Finally, I am convinced that statements forced by any form of ill-treatment, also administrated by private individuals, can never be used against a defendant being a victim of this ill-treatment. An opposing view would violate the right to silence and privilege against self-incrimination.

\section{References}

BOJAŃCZYK, Antoni. Dowód prywatny w postępowaniu karnym w perspektywie prawnoporównawczej. Warsaw 2011, Wolters Kluwer Publisher, pp. 21-177.

COMMITTEE AGAINST TORTURE decision of 21 November 2002, P.E. v. France, Comm. No. 193/2001, U.N. Doc. A/58/44, at 135 (CAT 2002)).

http://www.worldcourts.com/cat/eng/decisions/2002.11.21_PE_v_France.htm COMMITTEE AGAINST TORTURE decision of 21 November 2002, Hajrizi Dzemajl et al. v. Yugoslavia, Comm. No. 161/2000, U.N. Doc. CAT/C/29/D/161/2000 (2002). Available at:

https://www.ohchr.org/Documents/Publications/SDecisionsCATVolIen.pdf. Accessed on November 15, 2020.

Council of Europe Convention on the Protection of Human Rights and Fundamental Freedoms,

adopted on 4 November 1950. Available at: https://www.coe.int/en/web/ conventions/full-list/-/conventions/rms/0900001680063765. Accessed on November 11, 2020.

DECLARATION ON THE PROTECTION OF ALL PERSONS FROM BEING SUBJECTED TO TORTURE AND OTHER CRUEL, INHUMAN OR DEGRADING TREATMENT OR PUNISHMENT, adopted by General Assembly resolution 3452 (XXX) of 9th December 1975. Available at: https://www.ohchr.org/en/ professionalinterest/pages/declarationtorture.aspx. Accessed on November 6, 2020.

EXTRAORDINARY CHAMBERS IN THE COURTS OF CAMBODIA (TRIAL CHAMBER) decision of 5th February 2016, case no. 002/19-09-2007/ECCC/ TC. Available at: https://www.eccc.gov.kh/sites/default/files/documents/ courtdoc/2016-02-11\%2018\%3A14/E350_8_EN.PDF. Accessed: November 10, 2020. 
EUROPEAN COURT OF HUMAN RIGHTS judgment of 12th July 1988, Schenk v. Switzerland, appl. no. 10862/84.

EUROPEAN COURT OF HUMAN RIGHTS [Grand Chamber] judgment of 29 April 1997, H.L.R. v. France, appl. no. 24573/94.

EUROPEAN COURT OF HUMAN RIGHTS judgment of 23rd September 1998, A. v. UK, appl. no. $25599 / 94$.

EUROPEAN COURT OF HUMAN RIGHTS judgment of 11th February 2002, Visser $v$. the Netherlands, appl. no. 26668/95.

EUROPEAN COURT OF HUMAN RIGHTS decision of 25th May 2004, Arnold G. Cornelis v. the Netherlands, appl. no. 994/03.

EUROPEAN COURT OF HUMAN RIGHTS [Grand Chamber] judgment of 11th July 2006, Jalloh v. Germany, appl. no. 54810/00.

EUROPEAN COURT OF HUMAN RIGHTS judgment of 31st May 2007, Šečić v. Croatia, appl. no. 40116/02.

EUROPEAN COURT OF HUMAN RIGHTS [Grand Chamber] judgment of 10th March 2009, Bykov v. Russia, appl. no. 4378/02.

EUROPEAN COURT OF HUMAN RIGHTS judgment of 25th June 2009, Beganović v. Croatia, appl. no. 46423/06.

EUROPEAN COURT OF HUMAN RIGHTS [Grand Chamber] judgment of 1st June 2010, Gäfgen v. Germany, appl. no. 22978/05.

EUROPEAN COURT OF HUMAN RIGHTS judgment of 12th February 2012, Othman (Abu Qatada) v. United Kingdom, appl. no. 8139/09.

EUROPEAN COURT OF HUMAN RIGHTS judgment of 25th September 2012, El Haski v. Belgium, appl. no. 649/08.

EUROPEAN COURT OF HUMAN RIGHTS judgment of 11th February 2014, Cěsnieks v. Latvia, appl. no. 9278/06.

EUROPEAN COURT OF HUMAN RIGHTS judgment of 24th July 2014, Al-Nashiri v. Poland, appl. no. 28761/11.

EUROPEAN COURT OF HUMAN RIGHTS judgment of 24th July 2014, Husayn (Abu Zubaydah) v. Poland, appl. no. 7511/13.

EUROPEAN COURT OF HUMAN RIGHTS judgment of 3 March 2016, Prade $v$. Germany, appl. no. 7215/10.

EUROPEAN COURT OF HUMAN RIGHTS judgment of 16th June 2016, R.D. $v$. France, appl. no. 34648/14. 
EUROPEAN COURT OF HUMAN RIGHTS [Grand Chamber] judgment of 13th September 2016, Ibrahim and Others $v$. the United Kingdom, appl. nos. 50541/08, 50571/08, 50573/08 and 40351/09.

EUROPEAN COURT OF HUMAN RIGHTS judgment of 15th October 2019, Mehmet Ali Eser v. Turkey, appl. no. 1399/07.

EUROPEAN COURT OF HUMAN RIGHTS judgment of 5th December 2019, Hambardzumyan v. Armenia, appl. no. 43478/11.

EUROPEAN COURT OF HUMAN RIGHTS judgment of 22 October 2020, Bokhonko v. Gorgia, appl. no. 6739/11.

EUROPEAN COURT OF HUMAN RIGHTS judgment of 5th November 2020, Ćwik v. Poland, appl. no. 31454/10.

GENERAL COMMENT NO. 20: ARTICLE 7 (PROHIBITION OF TORTURE OR OTHER CRUEL, INHUMAN OR DEGRADING TREATMENT OR PUNISHMENT) adopted at the forty-fourth session (1992). Available at:

https://tbinternet.ohchr.org/_layouts/15/treatybodyexternal/TBSearch. aspx?Lang=en\&TreatyID=8\&DocTypeID=11. Accessed on November 20, 2020.

GENERAL COMMENT NO. 32, ARTICLE 14: RIGHT TO EQUALITY BEFORE COURTS AND TRIBUNALS AND TO A FAIR TRIAL), adopted at the ninetieth session, (2007), ccpr/c/gc/32. Available at: http://docstore.ohchr.org/SelfServices /FilesHandler.ashx?enc=6QkG1d\%2fPPRiCAqhKb7yhsrdB0H115979OVGGB\% 2bWPAXhRj0XNTTvKgFHbxAcZSvX1OsJj\%2fiyRmVA4IiMvUt2NlGKqqg 2nh1qOE2hX5xoGtKE2v2YSQVV1Rv5NitNbSYwp. Accessed on November $13,2020$.

GRAFFIN, Neil J. The legal consequences of ill-treating Detainees held for Police Questioning in Breach of Article 3 ECHR. European Journal of Current Legal Issues, v. 20, n. 2, 2014. Available at: http://webjcli.org/index.php/webjcli/article/ view/339. Accessed on November 11, 2020.

GREER, Steven. Is the Prohibition against Torture, Cruel, Inhuman and Degrading Treatment Really 'Absolute' in International Human Rights Law? Human Rights Law Review 2015. pp. 1-37. (advance access published on January 30, 2015). Doi: 10.1093/hrlr/ngu035. Available at: https://www.corteidh.or.cr/tablas/r33346. pdf. Accessed on November 13, 2020.

HOFMAŃSKI, Piotr; WRÓBEL, Andrzej, Artykuł 6. In: GARLICKI Lech (org.). Konwencja o ochronie praw człowieka i podstawowych wolności. Tom I. Komentarz do artykułów 1-18, Warsaw: C.H. Beck Publishing, 2010. pp. 241-461.

JASIŃSKI, Wojciech; CHOJNIAK, Łukasz. The Admissibility of Evidence Obtained by Torture and Inhuman or Degrading Treatment in Criminal Proceedings. 
Overview of European and Polish Standards. In: FENYVESI, Csaba; HERKE Csongor (org.). Pleadings. Celebration Volume of Professor Tremmel Florian's 70th Birthday. 148 Studia Iuridica Auctoritate Universitatis Pecs Publicata I (2011). Pecs 2011. pp. $125-134$.

JASIŃSKI, Wojciech. Nielegalnie uzyskane dowody w procesie karnym. W poszukiwaniu optymalnego rozwiązania. Wolters Kluwer Publishing, Warsaw 2019.

KUCZYŃSKA, Hanna. Prawo dowodowe w postępowaniu przed Międzynarodowym Trybunałem Karnym. In: SKORUPKA Jerzy (org.) System Prawa Karnego Procesowego. Dowody. Tom VIII, cz. 2, Wolters Kluwer Publisher. Warsaw 2019. pp.1688-1752.

LAI HO, Hock. The Fair Trial Rationale for Excluding Wrongfully Obtained Evidence, In: GLESS Sabine; RICHTER Thomas (org.). Do Exclusionary Rules Ensure a Fair Trial? A Comparative Perspective on Evidentiary Rules. Ius Gentium: Comparative Perspectives on Law and Justice 74. Springer Open, pp. 285-288.

https://doi.org/10.1007/978-3-030-12520-2

MONINA, Giuliana. Article 15. Non-Admissibility of Evidence Obtained by Torture. In: NOWAK, Manfred; BIRK Moritz; MONINA Giuliana (org.). The United Nations Convention Against Torture and Its Optional Protocol. A Commentary. Oxford University Press 2019. pp. 417-440.

PATTENDEN, Rosemary. Admissibility in criminal proceedings of third party and real evidence obtained by methods prohibited by UNCAT. International Journal of Evidence and Proof, v. 10, n. 1. 2006. pp. 1-41. https://doi.org/10.1350/ ijep.2006.10.1.1

RUSINEK, Michał. Zakazy odnoszące się do sposobu dowodzenia. In: SKORUPKA Jerzy (org.) System Prawa Karnego Procesowego. Dowody. Tom VIII, cz. 2, Wolters Kluwer Publisher. Warsaw 2019. pp. 2213-2315.

SCHARF, Michael P. Tainted Provenance: When, If Ever, Should Torture Evidence Be Admissible?, Case Research Paper Series in Legal Studies. Working Paper 07-27, September 2007. Available at:

ht t ps: // scholarlycommons.law.wlu.edu/cgi/viewcontent. cgi?article=1092\&context=wlulr. Accessed on November 20, 2020.

SOLODOV, Denis; SOLODOV, Ilia. Legal safeguards against involuntary criminal confessions in Poland and Russia. Revista Brasileira de Direito Processual Penal, Porto Alegre, vol. 6, n. 3, p. 1661-1698, set./dez. 2020. https://doi.org/10.22197/ rbdpp.v6i3.368 
THIENEL, Tobias. The admissibility of evidence obtained by torture under international law. European Journal of International Law, v. 17, n. 2, 2006, pp. 349-367. https://doi.org/10.1093/ejil/chl001

TRECHSEL, Stefan; SUMMERS, Sarah, J. Human Rights in Criminal Proceedings, Oxford University Press, Oxford 2006.

UNITED NATIONS CONVENTION AGAINST TORTURE AND OTHER CRUEL, INHUMAN OR DEGRADING TREATMENT OR PUNISHMENT, adopted on 10 December 1984. Available at: https://www.ohchr.org/en/professionalinterest/ pages/cat.aspx. Accessed on November 13, 2020.

WĄSEK-WIADEREK, Małgorzata, Model zakazów dowodowych z perspektywy Konwencji i orzecznictwa ETPCz. In: SKORUPKA Jerzy; DROZD Anna (org.). Nowe spojrzenie na model zakazów dowodowych w procesie karnym, Warsaw: C.H. Beck Publishing, 2015. pp. 20-41.

ZACH, Gerrit. Article 1. Definition of Torture. In: NOWAK, Manfred; BIRK Moritz; MONINA Giuliana (org.). The United Nations Convention Against Torture and Its Optional Protocol. A Commentary. Oxford University Press 2019. pp. 23-71.

\section{Additional information and author's declarations (scientific integrity)}

Conflict of interest declaration: the author confirms that there are no conflicts of interest in conducting this research and writing this article.

Declaration of authorship: all and only researchers who comply the authorship requirements of this article are listed as authors; all coauthors are fully responsible for this work in its entirety.

Declaration of originality: the author assures that the text here published has not been previously published in any other resource and that future republication will only take place with the express indication of the reference of this original publication; she also attests that there is no third party plagiarism or self-plagiarism. 


\section{Editorial process information}

(http://www.ibraspp.com.br/revista/index.php/RBDPP/about/editorialPolicies)

- Submission date: $14 / 12 / 2020$

Editorial team responsible

- Preliminary control and similarity verification:

- Editor-in-chief: 1 (VGV) 04/01/2021

- Review 1: 18/01/2021

- Review 2: 21/01/2021

- Associated-editor: 1 (KK)

- Reviewers: 3

- Review 3: 26/01/2021

- Editorial decision 1: 02/02/2021

- Correction round return: 19/02/2021

- Final editorial decision: 22/02/2021

\section{HOW TO CITE (ABNT BRAZIL):}

WAZSEK-WIADEREK, Małgorzata. Admissibility of Statements Obtained as a Result of "Private Torture" or "Private" Inhuman Treatment as Evidence in Criminal Proceedings: Emergence of a New European Standard? Revista Brasileira de Direito Processual Penal, Porto Alegre, vol. 7, n. 1, p. 343-374, jan./abr. 2021. https://doi.org/10.22197/rbdpp.v7i1.477

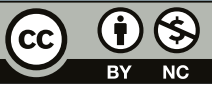

Esta obra está licenciada com uma Licença Creative Commons Atribuição-NãoComercial 4.0 Internacional. 